\title{
Zoosporic fungi growing on bird excrements in the water of the river Biala
}

\author{
BAZYLI CZECZUGA, BOŻENNA MAZALSKA \\ Department of General Biology, Medical Academy, Kilińskiego 1, \\ 15-230 Bialystok, Poland
}

$\mathrm{Cz}$ e z u g a B., M a z a $\mathrm{sk}$ a $\mathrm{B}$ : Zoosporic fungi growing on bird excrements in the water of the river Biala. Acta Mycol. 31 (1): 45-53, 1996.

The coprophilic fungi in the water of river Biala were studied. Samples of water were collected every other month for hydrochemical analysis and once (1994/95) in order to determine the fungus content. The excrements of 9 species of bird were used as bait.

Thirty-one species of coprophilic fungi were found in the water of the river Biala. Apodachlya punctata, Pythium catenulatum, Saprolegnia asterophora and S. megasperma new records for Poland.

Key words: Coprophilic fungi, river, hydrochemical study.

\section{INTRODUCTION}

Our studies on aquatic fungi in respective water bodies in north-eastern Poland with regard to the chemism of water (C z e c z u g a, $1991 \mathrm{a}, \mathrm{b} ; 1995$ a) have also included investigations of particular physiological groups of fungi. We have investigated vegetable saprophytes, examined species that parasitize on aquatic alga species (C z e c z u g a, W o r o n ow i c z, 1994) and described the occurrence of fungi of prey in the north-eastern region ( $\mathrm{C} \mathrm{z}$ e c z u g a, 1993). We have also established species growing on a keratin-containing substratum (C z e c z u g a, M u s z y ń s ka, 1994) and chitin-containing substratum (C z e c z u g a, G o d le w s k a, 1994) and on fish eggs (C z e c z u g a, W or on ow i c z, 1993).

The present work refers to the species growing on bird excrements, water birds in particular.

\section{MATERIALS AND METHODS}

The investigations included the excrements of the 9 bird species (Table 3).

The water for experiments were collected from the river Biała.

Eighteen parameters of these water samples were determined (Table 1) according to the generally accepted methods ( $\mathrm{G}$ o $1 \mathrm{t}$ e $\mathrm{r} \mathrm{m} \mathrm{a} \mathrm{n}, \mathrm{C} 1 \mathrm{y} \mathrm{m} \mathrm{o,1969).}$ 


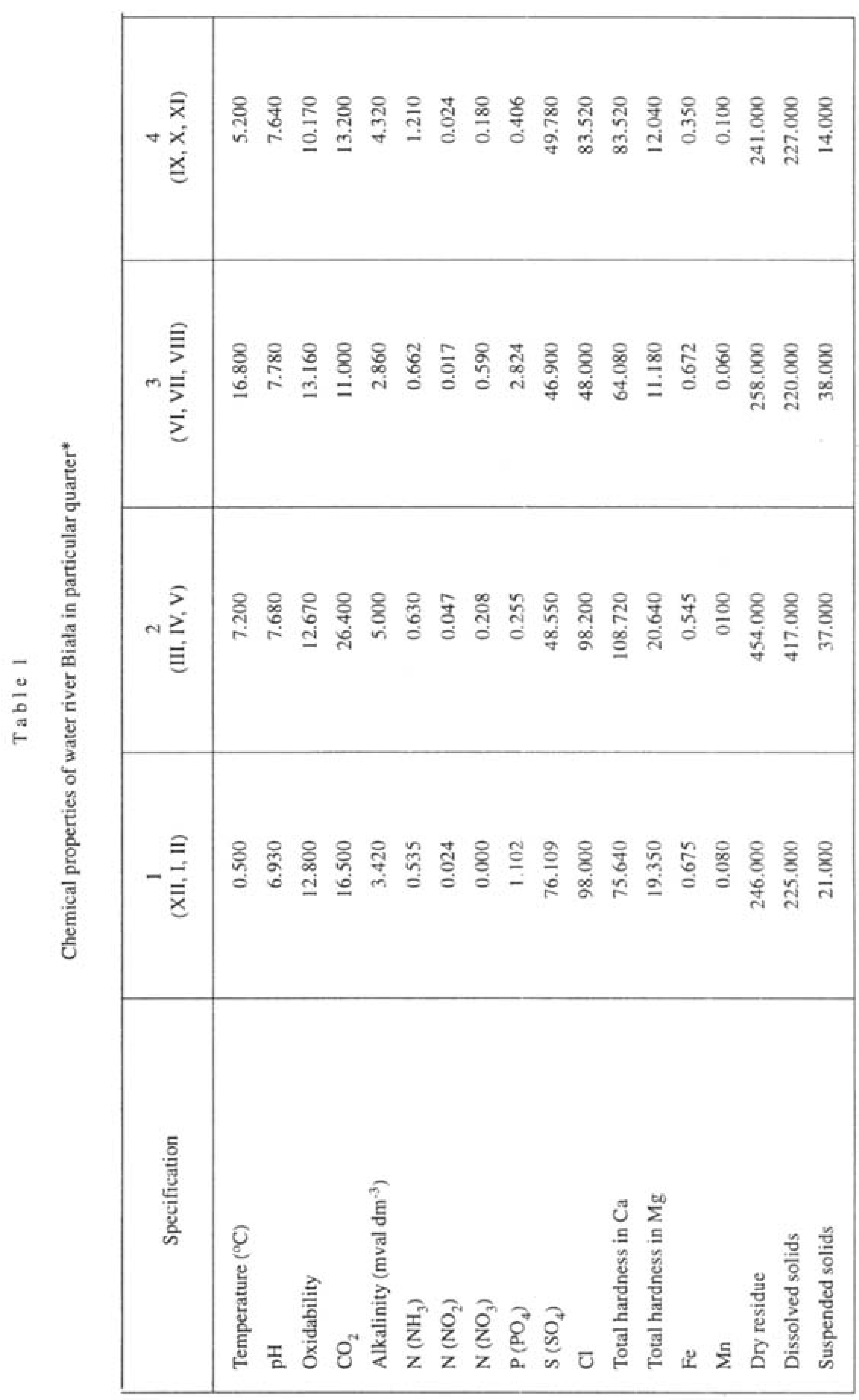

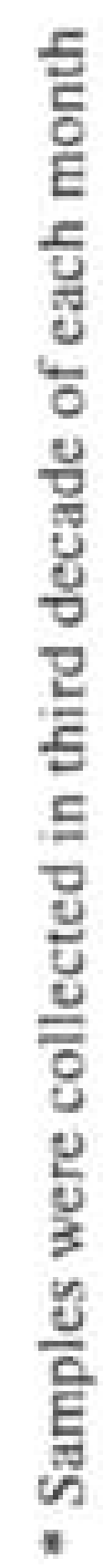


For the determinations of the presence of aquatic fungus species on the excrements, the following procedure was employed: certain amont of dry excrements $(0.5-1.0 \mathrm{~g})$ of each species of bird were transferred to two a 1.0 litre vessel and placed in the laboratory at a temperature approaching that of the given environment. The part of the excrements from each vessel was observed under a microscope and the mycelium (from zoospore, oognia and conidia) of aquatic fungi growing on the excrements was recorded. The methods were described in detail in paper F u 11 e r and $\mathrm{J}$ a w or $\mathrm{s} \mathrm{k}$ i (1986). The excrements of the various bird species were examined for one to one and half weeks.

For determinations of the fungi six keys were used ( $\mathrm{J}$ o h n s o n, 1956; S p a rr o w, 1960; S e y m o u r, 1970; K a r 1 in g, 1977; Kr e ger van R i j, 1984; D i c k, 1990).

\section{RESULTS}

In a one-year period, thirty-one zoosporic fungus species were found to grow in river water on excrements of 9 water birds or living on wet ground (Table 2). Most species were observed on excrements of white stork and mallard, fewest on excrements of marsh harrier and herrin gull (Table 3). The most common species in the respective months were Dictyuchus monosporus (marsh harrier, Roman-nosed goose, mute swan, grey heron and herrin gull), Leptomitis lacteus (mallard), Saprolegnia ferax (white stork, mallard) and Nowakowskiella elegans (greylag goose, muscovy duck) (Table 4). Several aquatic fungus species found on bird excrements were either new to the Polish mycoflora (Apodachlya punctata, Pythium catenulatum, Saprolegnia asterophora, Saprolegnia megasperma (Fig. 1), or rare (Pythium inflatum, Pythium rostratum and Pythium undulatum).
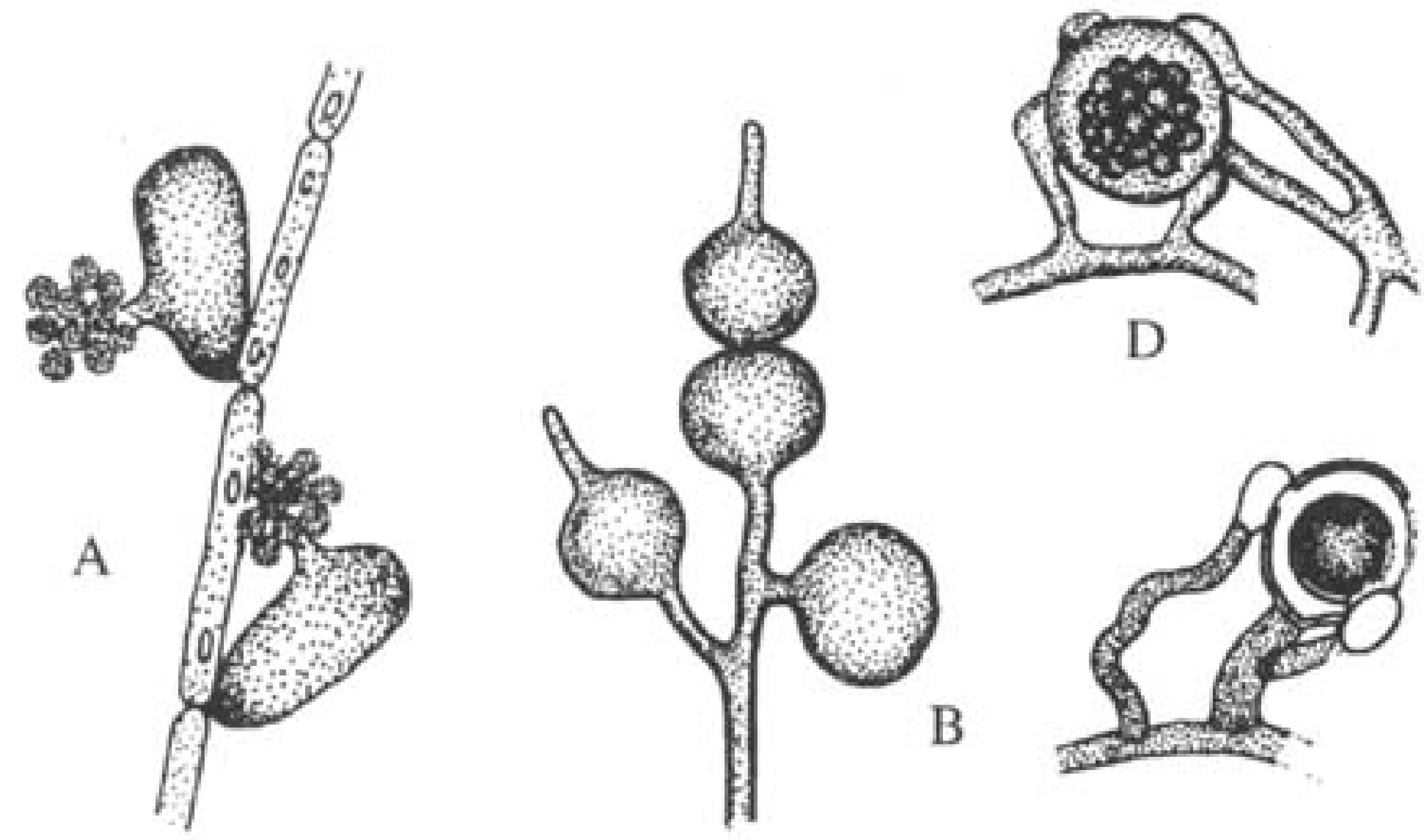

D

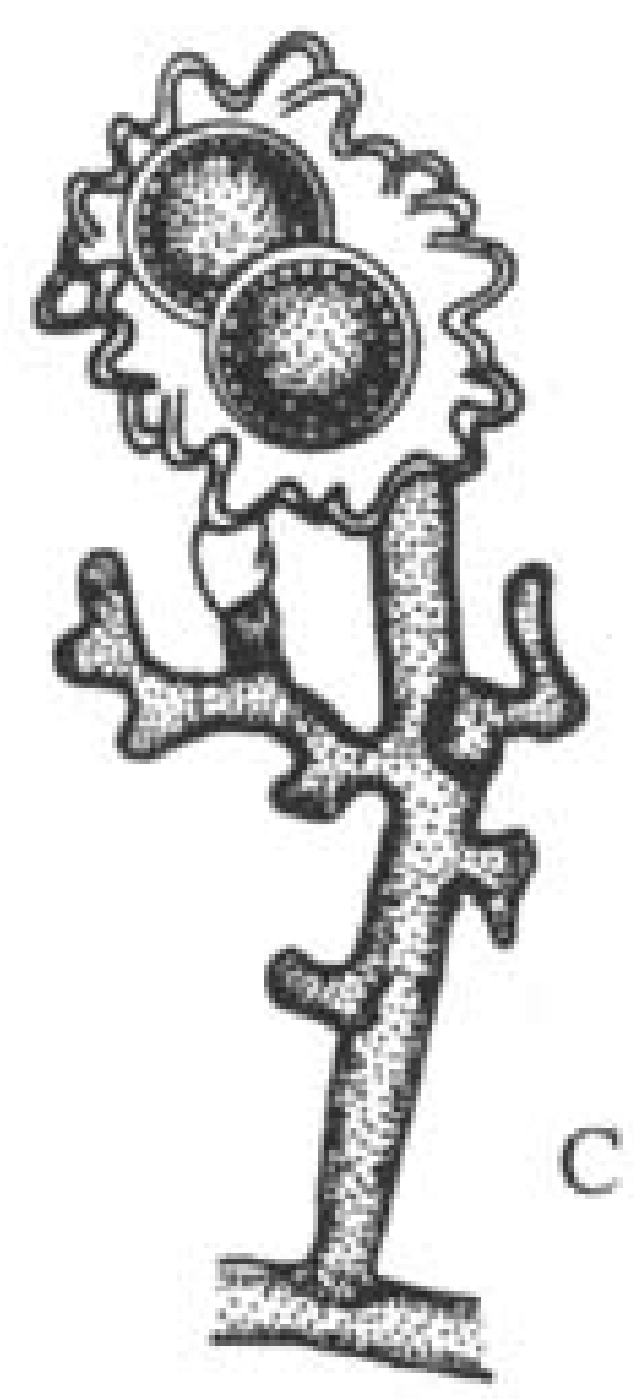

Fig. 1. Aquatic fungi new to mycoflora of Poland

$\mathrm{A}$ - Apodachlya punctafa (spore $-24 \times 52 \mu \mathrm{m}$ ); B - Pythium catenulatum (fragment hyphae and oogonium - 20-40 $\mu \mathrm{m})$; C - Saprolegnia asterophora (oogonium $-24-42 \mu \mathrm{m})$;

D - Saprolegnia megasperma (oogonium $-38-54 \mu \mathrm{m}$ ) 
$\mathrm{Tab} \mid \mathrm{e} 2$

Aquatic fungi were found on the excrements of bird

\begin{tabular}{|c|c|}
\hline Fungi & Bird (see Table 3) \\
\hline \multicolumn{2}{|l|}{ Chytridiomycetes } \\
\hline 1. Nowakowskiella elegans (Nowak.) Schroeter & $1,2,3,4,5,8$ \\
\hline 2. Rhizophlyctis petersenii Karling & $1,2,3,4,6$ \\
\hline \multicolumn{2}{|l|}{ Oomycetes } \\
\hline 3. Achlya colorata Pringsheim & 2,6 \\
\hline 4. Achlya dubia Coker & $3,5,7,9$ \\
\hline 5. Achlya glomerata Coker & 4 \\
\hline 6. Achlya orion Coker et Couch & 1,6 \\
\hline 7. Achlya papillosa Humphrey & 6 \\
\hline 8. Achlya polyandra Hildebrand & 6,9 \\
\hline 9. Achlya racemosa Hildebrand & 2,6 \\
\hline 10. Aphanodictyon papillatum Huneycutt & 9 \\
\hline 11. Aphanomyces laevis de Bary & $1,2,3,5,6,8$ \\
\hline 12. Aphanomyces irregularis Scott & 6 \\
\hline 13. Aphanomyces stellatus de Bary & 4,6 \\
\hline 14. Apodachlya pyrifera Zopf & 4,8 \\
\hline 15. Apodachlya punctata Minden & 8 \\
\hline 16. Cladolegnia unispora (Coker et Couch) Joh. & 6 \\
\hline 17. Dictyuchus monosporus Leitgeb & $1,2,3,4,5,6,7,8,9$ \\
\hline 18. Leptomitus lacteus (Roth) Agardh & $2,3,4,6,8,9$ \\
\hline 19. Pythium catenulatum Matthews & 2 \\
\hline 20. Pythium debaryanum Hesse & $1,2,5,6,8$ \\
\hline 21. Pythium inflatum Matthews & $1,2,3,4,6$ \\
\hline 22. Pythium rostratum Butler & $2,5,6,8$ \\
\hline 23. Pythium undulatum Petersen & $4,5,6,7$ \\
\hline 24. Pythium sp. & 2 \\
\hline 25. Saprolegnia asierophora de Bary & 3,8 \\
\hline 26. Saprolegnia diclina Humphrey & 2 \\
\hline 27. Saprolegnia ferax (Gruith) Thurnet & $2,4,5,6,7,8,9$ \\
\hline 28. Saprolegnia megasperma Coker & 2,6 \\
\hline 29. Saprolegnia monoica Prigsheim & 6 \\
\hline 30. Saprolegnia parasitica Coker & 6,8 \\
\hline 31. Zoophagus insidians Sommerstorff & 6,9 \\
\hline
\end{tabular}




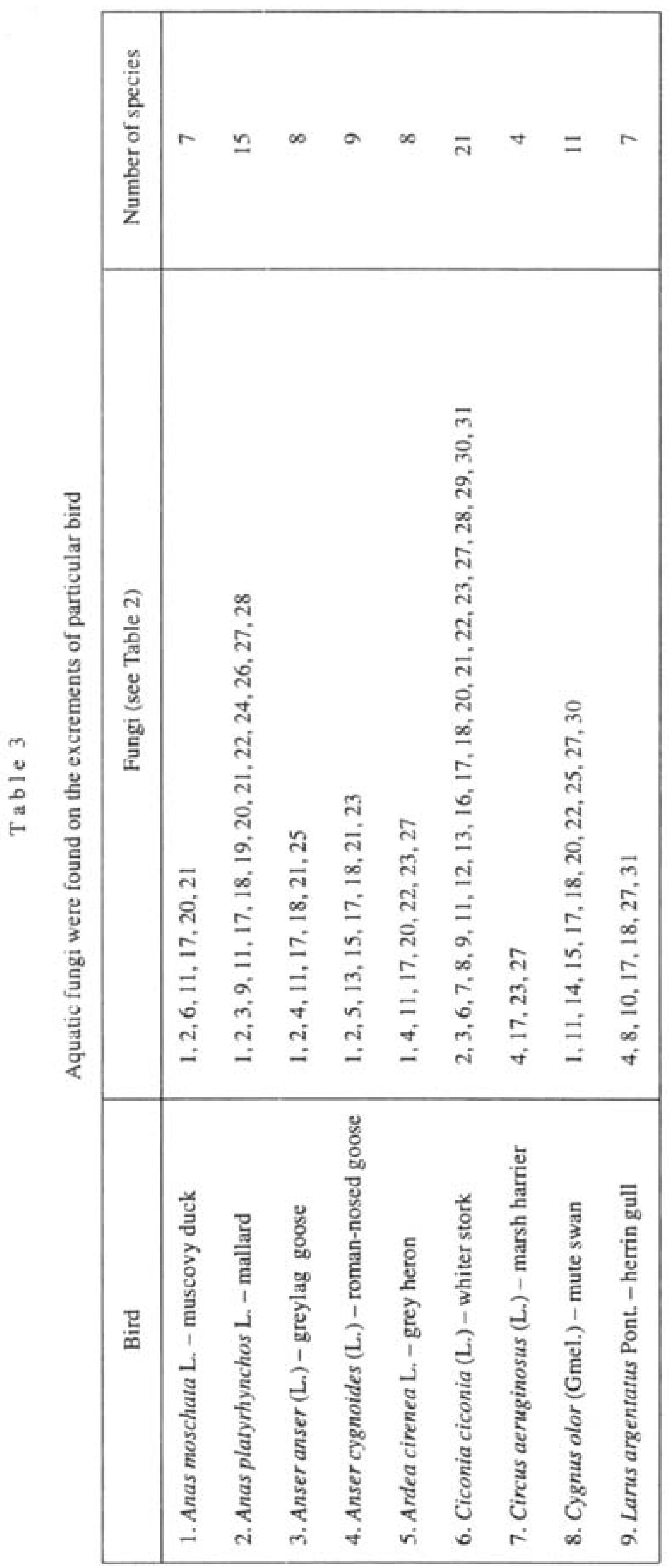




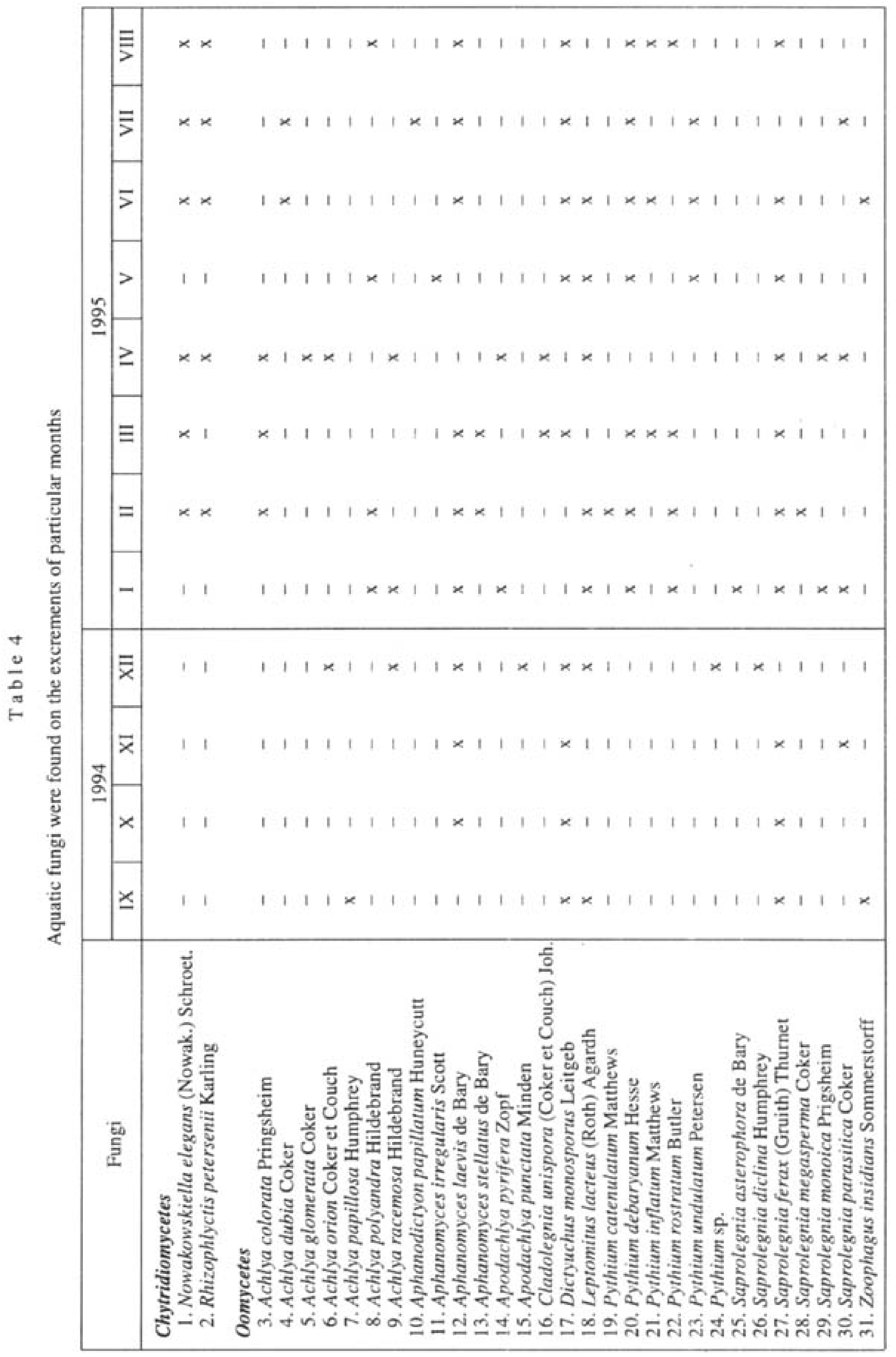




\section{DISCUSSION}

The fungus species observed on bird excrements, except those new to hydromycology of Poland, have been already found in a number of water bodies. Moreover, such species as Aphanomyces laevis, Aphanomyces irregularis, Achlya dubia, Saprolegnia ferax, Cladolegnia unispora and Leptomitus lacteus have been observed on chitin-containing substrata (C z e c z u g a, M u s z y ń s k a, 1994).

We have observed all species of the genus Achlya, except Achlya papillosa, several Saprolegnia species - Saprolegnia diclina, Saprolegnia ferax, Saprolegnia monoica, Saprolegnia parasitica, as well as Leptomitus lacteus and Dictyuchus monosporus on the eggs of a number of fish species (C z e c z u g a, W or o n o w i c z, 1993). This would indicate a wide substratum spectrum mineralized in water by the above mentioned zoosporic fungus species.

Worth special noting is the finding of four new and three rare fungus species on the bird excrements examined. Until the present study those fungus species have not been observed in the river Biala (C z e c z u g a et al., 1986) nor in other water bodies nor in the water of the river Biala, rich in baits, used for the studies of chitino- and keratinophilic fungi (C z e c z u g a, G o d l e w s k a, 1994; C z e c z u g a, M u$s \mathrm{z}$ y ń s k a, 1994). This would suggest that bird excrements used for the studies constitute a favourable substratum for the growth of these fungi. Apodachly punctata was found in December on excrements of mute swan. B a t k o (1975) found it on branches in water. Species of the genus Pythium is also knew to Poland, namely Pythium catenulatum. This species, known as an aquatic saprophyte (D i c k, 1990), was observed in our studies in February on excrements of mallard. Saprolegnia asterophora, a new species to Poland lives, according to $\mathrm{S}$ e y $\mathrm{m}$ o u $\mathrm{r}(1970)$, in water and soil of acidified nature. In waters it was encountered on sphagnum bogs on dead fish (H a y r e n, 1928). In our studies Saprolegnia asterophora developed only in January on excrements of greylag goose and mute swan. Saprolegnia was found in our studies on excrements of white stork and mallard only in February. In other countries it was observed in water and soil (S e y m o u r, 1970). We also found three rare species of the Pythium (Pythium inflatum, $P$. rostratum and $P$. undulatum). P. inflatum, also known as and aquatic saprophyte (P l a a t s - N i te r i n k, 1981), was observed in our studies on excrements of white stork (March), Roman-nosed goose (June, August), greylag goose (June) and muscovy duck (June). P. inflatum was earlirt encountered in the autumn in the river Węgorapa (C z e c z u g a, 1991 c). P. rostratum, known as a soil saprophyte (W a t a n a b e, 1988, 1991; I c h it a n i et al., 1992), rarely aquatic (S k i r g i e $1 \nmid$ o, 1954), in our studies was found on excrements of white stork (January, March), mallard (February, March), mute swan (January) and grey heron (August). Thus, it was found mainly in winter. It should be mentioned that I c h i t a n i et al. (1992) isolated the mycelium of $P$. rostratum from soil also in witner months. The other rare species $-P$. undulatum was observed in spring and summer months on excrements of marsh harrier, white stork, Roman-nosed goose and grey heron. $P$. rostratum was earlier eccountered in the late 
autumn in the river Biebrza near Osowiec (C z e c z u g a et al., 1990) and in the autumn in the oligotrophic lake Hańcza (C z e c z u g a, 1994), while $P$. undulatum in the heavily polluted river $\mathrm{Gac}$ in the same season ( $\mathrm{C} \mathrm{z} \mathrm{e} \mathrm{c} \mathrm{z} \mathrm{u} \mathrm{g} \mathrm{a,} 1995$ b).

The bird species used for the studies can be divided according to the type of nourishment into two groups: typically carnivorous (marsh harrier, white stork and grey heron) and with domination of vegetable food. In the latter group, the numbers of fungus species found on excrements of the respective animals are almost the same, while significant differences are found in the carnivorous group, which mainly referes to marsh harrier and white stork.

\section{REFERENCES}

B a t k o A., 1975. Zarys hydromikologii. PWN, Warszawa.

C z e e z u g a B., 1991 a. Aquatic fungi in lake Śniardwy and eighteen neighbourin lakes. Int. Revue ges. Hydrobiol. 76: 121-135.

C z e c z u g a B., 1991 b. The mycoflora of lake Wigry and seven adjacent lakes. Arch. Hydrobiol. 120: 495-510.

$\mathrm{C} z$ e c z u g a $\mathrm{B}_{+} 1991 \mathrm{c}$. Mycoflora of the river Weqgorapa and its tributary, the river Goldapa-Jarka. Acta hydrochim. hydrobiol. 19:517-528.

$\mathrm{C} \mathrm{z}$ e c z u g a B., 1993. The presence of predatory fungi in the waters on north-eastern Poland. Acta Mycol. 28: $211-217$.

C z e c z u g a B., 1994. Aquatic fungi of lake Haricza in the Suwalki Scenic Park and of some adjacent lakes (north-eastern Poland). Acta Hydrobiol. 36: 371-385.

C z e c z u g a B., 1995 a. Hydromycoflora of thirty-one lakes in Elk Lake District and adjacent waters with reference to the chemistry of the environment. Acta Mycol. 30: 49-63.

C z e c z u g a B., 1995 b. Mycoflora of the Narew river and its tributaries in the stretch between Tykocin and Ostrolęka. Acta Mycol. 30 (2): 181-191.

C z e c z u g a B., G o d l e w s k a A.. 1994. Aquatic fungi growing on substrates containing chitin. Acta Mycol. 29: 189-200.

C z e c z u ga B., M u s z y ń s ka E., 1994. Keratinophilic fungi in various types of water bodies. Acta Mycol. 29:201-215.

C z e c z u g a B., W or on ow i c z L., 1993. Aquatic fungi developing on the eggs of certain fresh-water fish species and other environment. Acta Icht. Piscat. 23: 38-57.

Czeczuga B., Wor o n ow i cz L., Brzozows ka K., 1986. Grzyby wodne rzeki Bialej na stanowiskach o różnym stopniu i charakterze zanieczyszczeń. Rocz. AM Bialystok 31: 49-61.

Czeczuga B., Wor on ow icz L., B rzozows k a K., 1990. Aquatic fungi of the lowland river Biebrza. Acta Mycol. 26: 77-83.

D i ck M. W., 1990. Keys to Pythium. College Estate Management Whiteknights, Reading, U.K., 64 pp.

Full e r M.S., J a w o rs ki A., 1986. Zoosporic fungi in teaching and research. South-eastern. Publ. Corpor. Arhens, $310 \mathrm{p}$.

Gol te r m a n H. L., Cl y mo R. S., 1971. Methods for physical and chemical analysis of fresh water. IBP Handb. No 8, Oxford Blackwell Sci. Publ.

H a y r è n E., 1928. Saprolegnia asterophora de Bary. Mem. Soc, pro Fauna et Flora Fennica 4: 50.

I ch it an i T., Kin osh ita T. and Okumura T., 1992. Materials for Pythium flora of Japan (V). Three species of Pythium from soil a vegetable garden in winter. Bull. Univ. Osaka Pref, Ser. B, 44: 13-16.

J o h n s on T. W., 1956. The genus Achlya: morphology and taxonomy. The University of Michigan Press, Ann. Arbor, Michigan, $180 \mathrm{pp}$.

Ka rl in g J. S., 1977. Chytridiomycetarum Iconographia. An Illustrated and Brief Descriptive Guide to the Chytridiomycelous genera with a supplement of the Hypochytriomyceies. Vaduz.

Pla ats - Niterink A. J. Van der., 1981. Monograph of the genus Pythium. Stud in Mycol. 21: 1-242.

S e y mo u r R. L., 1970. The genus Saprolegnia. Nova Hedwigia, 19 (1-2): 1-124. 


\title{
Grzyby zoosporowe rosnące na ptasich odchodach w rzece Białej
}

\author{
Streszczenie
}

Badano grzyby koprofiline w wodach rzeki Bialej. Próbki wody pobierano co miesiąc dla wykonania analizy hydrochemicznej oraz oznaczenia grzybów.

W próbach stwierdzono obecnošc 31 gatunków, które wyrosly na odchodach ptaków wodnych. Gatunkami nowymi dla mikoflory Polski okazaly się: Apodachlya punctata, Pythium catenulatum, Saprolegnia astrophora i S. megasperma. 


\title{
Effects of vitamins, temperature and $\mathrm{pH}$ on the biomass production by ectomycorrhizal fungi
}

\section{ALEKSANDRA POKOJSKA, MARIA KAMPERT, HENRYK RÓŹYCKI, EDMUND STRZELCZYK}

\author{
Laboratory of Microbiology, Institute of Biology and Environment Protection. \\ Nicolaus Copemicus University, Gagarina 9, 87-100 Toruń, Poland, Fax: +48 (56) 14-478
}

\begin{abstract}
Pokojska A., Kampert M., Róży ck i H., Strzelczy k E.: Effects of vitamins, temperature and pH on the biomass production by ectomycorrhizal fungi. Acta Mycol. 31 (1): 55-65, 1996.

Studies were carried out to determine the effect of vitamins, temperature and $\mathrm{pH}$ on the biomass production by ectomycorthizal fungi: Laccaria bicolor, Hebeloma crustuliniforme, Süllus bovinus and Pisolithus arhizus. Responses of particular organisms were different. Three-factor ANOVA which enables the comparison of the effect of experimental factors on biomass yield has shown that the $\mathrm{pH}$ of the medium had a stronger effect on $L$ bicolor, $H$. crustuliniforme and $S$. bovinus than vitamins. Temperature was the factor exerting the strongest effect on the growth of $P$. tinctorius.
\end{abstract}

\section{INTRODUCTION}

Vitamins are essential for the metabolism of animals, plants and microorganisms. They are components of coenzymes catalyzing important biochemical reactions ( 0 e r t $1 \mathrm{i}, 1987$ ). Many soil bacteria and saprophytic, pathogenic as well as symbiotic fungi are capable of producing and excreting into the environment vitamins like thiamine, folic acid, nicotinic acid, biotin (H u s s a i n, V a n č u r a, 1970; Strzelczyk, Leniarska, 1980, 1985; D a h m, Strze 1 czyk, Reddy, 1989; S trze l c z y k, D a h m, P a c h 1 e w s k i, 1991). At the same time some microorganisms are not able to produce one or several vitamins. Requirements of mycorrhizal fungi regarding vitamins were described by $\mathrm{N}$ or $\mathrm{k}$ a n s (1950), M e l in (1953), S I a n k is (1973). Among vitamins thiamine seems to be the most important one. According to P a I m e r (1971) thiamine must and biotin ought to be added to a satisfactory synthetic medium. Inositol, nicotinic acid and panthotenic acid also increase the growth of some fungal species ( $\mathrm{P}$ a $1 \mathrm{~m}$ e r, 1971).

The ecological importance of vitamins as growth stimulators of ectomycorrhizal fungi and mycorrhizae formation is far from being elucidated. It seems that vitamins 